\title{
Optimization of shell buckling incorporating Karhunen-Loève-based geometrical imperfections
}

\author{
K. J. Craig • Nielen Stander
}

Published online: 31 October 2008

(C) Springer-Verlag 2008

\section{Erratum to: Struct Multidisc Optim}

DOI 10.1007/s00158-007-0178-3

The correct classification for the above text is Research Paper.

The online version of the original article can be found at http://dx.doi.org/10.1007/s00158-007-0178-3.

K. J. Craig ( $\square)$

University of Pretoria,

Pretoria 0002, South Africa

e-mail: ken@up.ac.za

N. Stander

Livermore Software Technology Corporation,

Livermore, CA 94551, USA

e-mail: nielen@1stc.com 